UDC 37: 004.9

https://doi.org/10.36906/2500-1795/21-2/09

Moldabayeva K.E., Odanova S.A.

\title{
POSSIBILITIES OF USING THE ELECTRONIC EDUCATIONAL RESOURCES TO ENSURE THE INTERACTIVITY OF THE LEARNING PROCESS
}

\begin{abstract}
This article provides information on characteristics and classification of electronic educational resources according to the type and purpose of use. The main parameters of electronic educational resources such as electronic type of publication (resource); subject area of study; the proposed level of education; the proposed type of educational process; peculiarity of the audience are described in the article. The possibilities of using electronic educational resources to ensure the interactivity of the learning process are also considered, their advantages such as the ability to simulate various processes that replace the use of special equipment and reagents, interactivity, the possibility of network distribution, ease of information retrieval, openness for entering new data, compact storage data are also describes, as well as some disadvantages such as the possibility of information oversaturation of the educational process, the emergence of additional cognitive load, etc are noted in the article. The article also explains such types of electronic educational resources as a computer textbook (textbook, lecture notes, etc.), an electronic reference book, a computer book of tasks, a computer laboratory practice (models, simulators, etc.), a computer testing system that are widely used by teachers to increase the interactivity of the lessons. New types of e-learning resources that have become the most popular links with the transition to online learning like Zoom, Google meet, Google classroom, Microsoft teams and their role in improving the efficiency of the educational process are also described in this article. The role of the teacher and their tasks and goals and requirements, which have increased with the advent of digital educational resources, are also discussed in the article.
\end{abstract}

Keywords: e-learning resources, telecommunication technologies, information technology, digital platforms, multimedia, audio and video materials.

About the authors: Moldabayeva Karlygazh Ergazievna, ORCID: 0000-0002-6785-7848, Kazakh State Women Pedagogical University; Almaty University of Power Engineering and Telecommunication after G. Daukeev, Kazakhstan, Almaty, k.moldabaeva@aues.kz; Odanova Sagira Amangeldievna, Candidate of Philological Sciences, Kazakh State Women Pedagogical University, Kazakhstan, Almaty, sagira68@mail.ru 
Молдабаева К.Е., Оданова С.А.

\section{ВОЗМОЖНОСТИ ИСПОЛЬЗОВАНИЯ ЭЛЕКТРОННЫХ ОБРАЗОВАТЕЛЬНЫХ РЕСУРСОВ ДЛЯ ОБЕСПЕЧЕНИЯ ВЗАИМОДЕЙСТВИЯ В ПРОЦЕССЕ ОБУЧЕНИЯ}

Аннотация. В статье представлены характеристика, классификация электронных образовательных ресурсов согласно типу, виду и цели использования. Рассматриваются основные параметры электронных образовательных ресурсов, таких как: электронный вид публикации (ресурс); предметная область обучения; предлагаемый уровень образования; предлагаемый вид учебного процесса; особенность аудитории. Так же рассматриваются возможности применения электронных образовательных ресурсов для обеспечения интерактивности процесса обучения, описываются их преимущества такие как: возможность моделирования различных процессов заменяющих использование специального оборудования и материалов, интерактивность - возможность сетевого распространения, удобство поиска информации, открытость для внесения новых данных, компактность хранения данных, а также некоторые недостатки: как возможность информационного перенасыщения учебного процесса, возникновение дополнительной когнитивной нагрузки и т. д. Так же в статье дается объяснение таким видам электронных образовательных ресурсов, как компьютерный учебник (учебник, конспект лекций и др.), электронный справочник, компьютерная книга задач, компьютерный лабораторный практикум (модели, тренажеры и др.), система компьютерного тестирования, которые широко используются преподавателями для повышения интерактивности уроков. Новые виды электронных образовательных ресурсов, которые стали наиболее популярными в связи с переходом на онлайн обучение, как Zoom, Google meet, Google classroom, Microsoft teams и их роль при повышении эффективности учебного процесса также описывается в данной статье.

Ключевые слова: электронные образовательные ресурсы; телекоммуникационные технологии; информационные технологии, цифровые платформы, мультимедиа, языковые модели.

Сведения об авторах: Молдабаева Карлыгаш Ергазиевна, ORCID: 0000-0002-67857848, Казахский государственный женский педагогический университет; Алматинский университет энергетики и связи им. Гумарбека Даукеева, Казахстан, г. Алматы, k.moldabaeva@aues.kz; Оданова Сагира Амангельдиевна, канд. филол. наук, Казахский государственный женский педагогический университет, Казахстан, г. Алматы, sagira68@mail.ru

Moldabayeva K.E., Odanova S.A. Possibilities of Using the Electronic Educational Resources to Ensure the Interactivity of the Learning Process // Нижневартовский филологический вестник. 2021. № 2. С. 97-104. https://doi.org/10.36906/2500-1795/21-2/09 
Moldabayeva, K.E., \& Odanova, S.A. (2021). Possibilities of Using the Electronic Educational Resources to Ensure the Interactivity of the Learning Process. Nizhnevartovsk Philological Bulletin, (2), 97-104. https://doi.org/10.36906/2500-1795/21-2/09

Today, electronic resources represented on the Internet are used in all spheres of society, and modern telecommunication technologies are also widely used in education process. Using elearning resources simplifies the search for vital information by applying the necessary online platforms for schoolchildren, university students and teachers.

E-learning resources are one of the most effective forms of learning and an important tool for improving its quality. Changes in teaching aids should lead to the restructuring of the entire system of educational process, as the widespread use of e-learning resources changes the content of educational materials, forms and methods of teaching, as well as the activities of the subjects of the educational process.

The introduction of electronic teaching aids in the educational process will help to solve the problem of achieving qualitatively new educational results, the correct combination of e-learning resources with traditional teaching aids and methods is a necessary factor in their proper use. Elearning resources expand the possibilities of the educational process, but at the same time they remain only a tool, so it is important to use them correctly and appropriately.

Thus, the rapid development of information technology has created a new form of e-learning, as well as a comprehensive acquaintance with e-learning resources for teachers in order to effectively use these resources in education process and organize lessons in accordance with modern requirements and to be able to classify them.

Since there are different ways to classify e-learning resources, here are a few of them. It is impossible to fully define the universal classification of educational disciplines in terms of general educational resources. This is primarily due to the wide variety of thematic areas covered by various e-learning resources.

If we consider that their classification should reflect not only the topic, but also the technology of resources, then it is necessary to highlight the main parameters that characterize them, which can then form the basis of classification criteria.

According to B.B. Kosulin and S.M. Kutsenko, in terms of the educational process organization, the following basic parameters can be distinguished. They are:

- electronic publication type (resource);

- the subject area of education;

- the proposed level of education;

- the proposed type of educational process;

- the peculiarity of the audience (Kutsenko, Kosulin 2017: 23).

On the one hand, according to their functions, e-learning resources can be classified as traditional educational publications and, accordingly, described using the classification principles used for traditional textbooks. 
On the other hand, they belong to the category of electronic publications and can be applied to the principles of classification of electronic publications. Third, many e-learning resources are software products. Depending on the above types, it will be convenient to classify them according to the characteristics that actually define them, in particular, S.M. According to Kutsenko depending on theire types, e-learning resources are divided into the following parts:

- on a functional basis, which determines the importance and place in the learning process;

- organization of the resource text;

- nature of the information provided;

- presentation;

- for the intended purpose;

- availability of a printed equivalent;

- format (nature) of basic information;

- distribution technology;

- the nature of the interaction with the user.

In addition, the author distinguishes the following groups of the main e-learning resources, depending on their type:

- computer textbook (textbook, lecture notes, etc.);

- electronic reference book;

- computer problem book;

- computer laboratory practice (models, simulators, etc.);

- computer testing system.

The computer textbook is designed for independent study of theoretical material and can be text, hypertext or multimedia. It contains structured learning materials for students. The hypertext structure allows the student to determine the optimal trajectory of the study of the material and a convenient pace of work that corresponds to the specifics of its perception.

The reference book of computer problems allows you to create methods for solving typical problems that allow you to visually connect theoretical knowledge with specific problems aimed at solving them.

Computer workshops, models, designers and simulators allow you to consolidate knowledge and gain skills to apply them in practice. Computer laboratory practice allows you to simulate the processes that take place in the studied real objects or to simulate an experiment that is impossible in a real situation.

Laboratory simulators allow you to choose the optimal parameters of the experiment, gain initial experience and skills in preparation, simplify and accelerate work with specific experimental equipment and facilities.

The computer testing system can be a separate program or a universal software that does not allow modification. Typically, such systems are equipped with a subsystem of test preparation that simplifies the process of their creation and conversion. The efficiency of using the testing system will be significantly higher if it allows to collect and analyze test results (Danilova 2010: 28). 
According to researchers, depending on the basic information format, e-learning resources are divided into the following types:

- text - an electronic publication containing mainly textual information;

- graphic - an electronic edition, presented in a form that mainly contains graphic objects, allows you to view and print, but does not allow editing;

- audio - an electronic publication that contains a digital view of audio information, allows you to listen, but is not intended for publication in hard copy;

- software - stand-alone software product, which is the publication of text in some standalone software environment;

- multimedia - an electronic publication in which information of different nature is interconnected to achieve the didactic goals set by the developer (Engeness 2021).

E.A. Akolzina describes e-learning resources as computer tools that teachers can design and use to achieve learning objectives, noting a number of their advantages based on innovative criteria for evaluating the effectiveness of the use of electronic resources:

1) multimedia presentation of information, which allows you to effectively master the material. First, psychological and pedagogical research has shown that the effectiveness of training depends on the degree of activation of all sensory organs. Because multimedia affects the human senses at the same time, the quality of the subject increases.

Second, the diversity of information allows you to independently master the presented material, which in turn contributes to the activation of cognitive activity and the formation of innovative thinking;

2) the ability to simulate various processes that replace the use of special equipment and reagents in laboratories;

3) interactivity;

4) possibility of network distribution;

5) convenience of finding information;

6) ease of entering new data;

7) compactness of data storage (Akolzina 2013: 22).

In addition, analyzing the work of specialists, the author notes a number of significant shortcomings in the use of electronic resources:

1) The technologicalization of the educational process contributes to the formation of excessive individualism, and, consequently, leads to the destruction of integrity, focusing only on the individual. Constant work on the Internet contributes to the problem of personal information security;

2) The problem of purchasing modern equipment that meets the latest requirements of elearning resources;

3) The emergence of additional cognitive pressure. It can be concluded that the cognitive load is the result of improper structuring of information. Too many hyperlinks in the wrong places can 
lead to negative consequences, as a result of which the user may deviate from the educational trajectory.

4) the problem of developing theoretical skills in the information environment while the implementation of psychological and pedagogical learning objectives.

Full mastery of e-learning resources, the ability to use them effectively in improving the quality of the subjects they teach requires hard work, a wide range of knowledge, skills and abilities of teachers. Teachers' competence in digital technology is defined as a two-way structure that, on the one hand, constantly develops its competence in digital technology as a professional, and on the other hand, enhances the development of the digital system through learning experiences.

Based on the classical theories of teachers' practice, the Organization for Economic Cooperation and Development emphasizes that the professional skills of teachers in improving their skills in the use of e-learning resources consists of three main areas, including professional education - teaching and learning recognized as a set of knowledge and skills; Electronic instruction planning, classroom standards and ethics of behavior in front of the camera are considered as a key component of classical professionalism (Dovgan VV 2012: 18).

In accordance with modern requirements, e-learning resources are widely used in the educational space of the country. Due to the transition of the educational process to the online format in secondary schools and universities, new platforms are being introduced, including Zoom, Google meet, Google classroom, Microsoft teams. Using these programs, teachers have the opportunity to share their videos, audio materials, presentations and lectures with students, as well as the Platonus platform, which assesses students' knowledge, allows them to assign homework and feedback to the teacher.

One of the most effective applications for learning a foreign language is Learning Apps, which is used for learning not only English, but also for all fields of science. The application is designed to support learning and teaching through small publicly available interactive modules. These exercises are created online and can later be used in the educational process. To create such exercises, the site offers several templates (classification exercises, multiple choice tests, etc.). These exercises are not complete learning units and should be integrated into the learning scenario. If we talk about the use of this application, it greatly facilitates the teacher's work because all topics are divided into categories that can be used while consolidating and introducing new material on topics. In given picture you can see the main page of the application "Learning apps": 


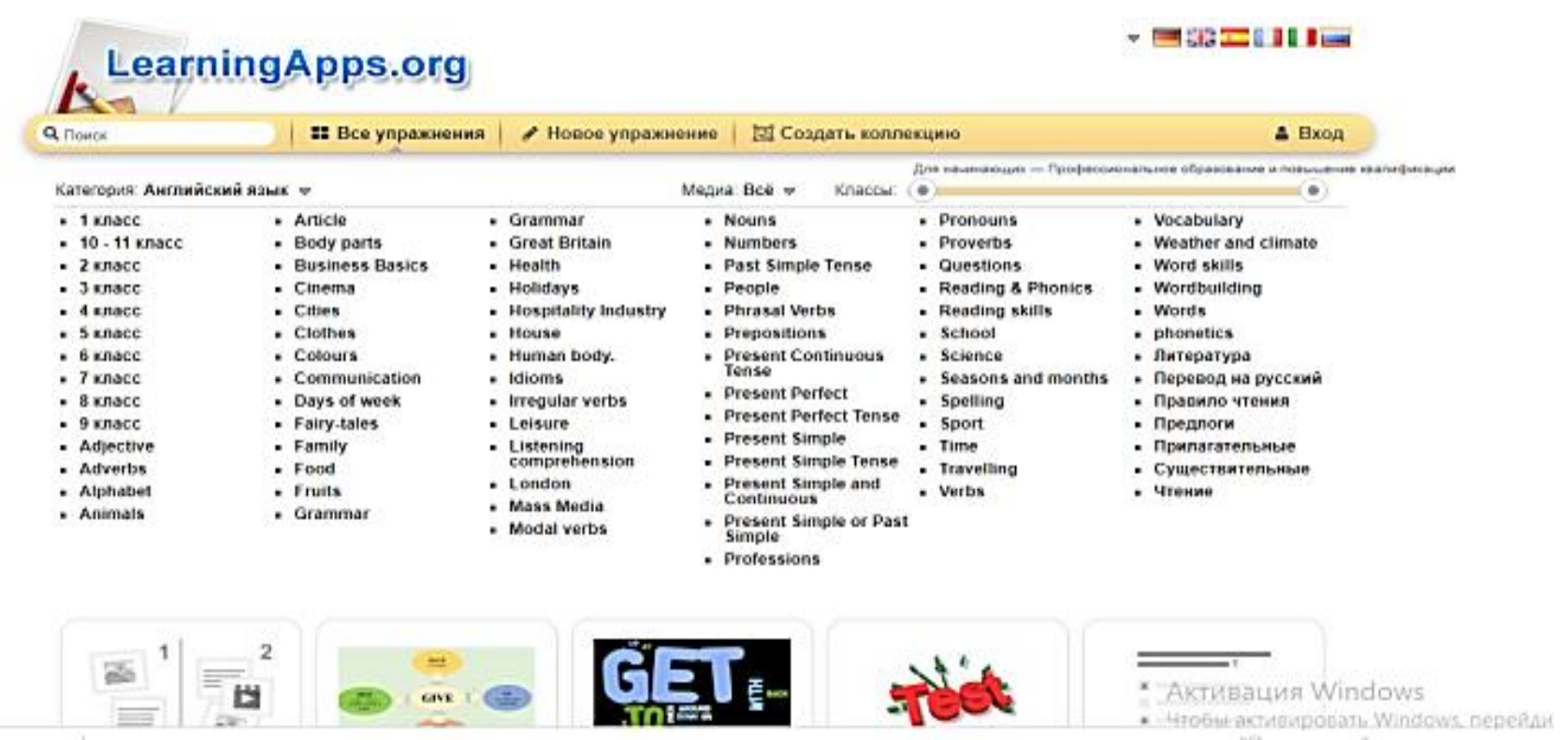

Picture. Application directory (https://learningapps.org/)

In addition, in order to become one of the most experienced professionals of the 21 st century, teachers are invited to become digitally literate agent-practitioners in order to improve their professional knowledge, master independent decision-making and work with colleagues and students (Liljekvist 2021).

Thus, in conclusion, due to the formation of the information society, e-learning resources have become an integral part of the educational process. By promoting the development of information competence, they contribute to the formation of a competitive personality in the labor market. Having additional innovative features compared to traditional textbooks, e-learning resources increase the importance of independent learning activities of students; increase the creative activity of teaching staff and stimulate the development of new electronic resources.

\section{REFERENCES}

Engeness, I. (2021). Developing teachers' digital identity: towards the pedagogic design principles of digital environments to enhance students' learning in the 21st century. European Journal of Teacher Education, 44(1), 96-114. https://doi.org/10.1080/02619768.2020.1849129

Liljekvist, Y. E., Randahl, A. C., van Bommel, J., \& Olin-Scheller, C. (2021). Facebook for professional development: Pedagogical content knowledge in the centre of teachers' online communities. Scandinavian Journal of Educational Research, 65(5), 723-735. https://doi.org/10.1080/00313831.2020.1754900

Akol'zina, E.A. (2013). Ispol'zovanie elektronnykh obrazovatel'nykh resursov v protsesse obucheniya: dostoinstva i nedostatki. Gaudeamus: Psikhologo-pedagogicheskii zhurnal, (2 (22)), 95-97. (in Russian).

Danilova, O.V. (2010). Podgotovka studentov pedagogicheskogo vuza $\mathrm{k}$ razrabotke elektronnykh obrazovatel'nykh resursov: Dis. ... kand. ped. nauk. Cheboksary. (in Russian). 
Dovgan, V.V. (2012). Sozdanie i ispol'zovanie elektronnogo obrazovatel'nogo resursa v sostave informatsionno-metodicheskogo obespecheniya uchebnogo protsessa: Dis. ... kand. ped. nauk. Moscow. (in Russian).

Kutsenko, S.M., \& Kosulin, V.V. (2017). Elektronnye obrazovatel'nye resursy kak instrument obucheniya. Vestnik Kazanskogo gosudarstvennogo energeticheskogo universiteta, (4 (36)), 127134. (in Russian).

\section{ЛИТЕРАТУРА}

Engeness I. Developing teachers' digital identity: towards the pedagogic design principles of digital environments to enhance students' learning in the 21st century // European Journal of Teacher Education. 2021. V. 44. №. 1. P. 96-114.

Liljekvist Y.E., Randahl A.C., van Bommel J., Olin-Scheller C. Facebook for professional development: Pedagogical content knowledge in the centre of teachers' online communities // Scandinavian Journal of Educational Research. 2021. V. 65. №. 5. P. 723-735. https://doi.org/10.1080/00313831.2020.1754900

Акользина Е.А. Использование электронных образовательных ресурсов в процессе обучения: достоинства и недостатки // Гаудеамус: Психолого-педагогический журнал. 2013. № 2 (22). С. 95-97.

Данилова О.В. Подготовка студентов педагогического вуза к разработке электронных образовательных ресурсов: Дис. ... канд. пед. наук. Чебоксары, 2010. 180 с.

Довгань В.В. Создание и использование электронного образовательного ресурса в составе информационно-методического обеспечения учебного процесса: Дис. ... канд. пед. наук. М., 2012. 139 с.

Куценко С.М., Косулин В.В. Электронные образовательные ресурсы как инструмент обучения // Вестник Казанского государственного энергетического университета. 2017. № 4 (36). C. $127-134$.

(C) Moldabayeva K.E., Odanova S.A., 2021 